\section{Kejahatan Terorganisir Terhadap Pelacuran Anak Di Kota Medan Ditinjau Dari Psikologi Kriminil (Studi Penelitian di Kota Medan)}

oleh:

\section{Muhammad Ridwan Lubis ${ }^{1}$ Gema Rahmadani ${ }^{2}$}

Email : muhammadridwanlubis76@gmail.com

\section{Abstract}

Crimes that used to be committed by individuals are now mostly committed by organized groups where the legal force of the group is illegal. Theft, muggings, fraud, murder, corruption, money loundry, prostitution, terrorism are some forms of the crime that are mostly committed in an organized manner.

The development of the world of the child prostitution has spread in various big cities in Indonesia, including Medan. The sparkling of the city has attracted many people who come from various places in Indonesia and outside Indonesia who want to taste the sweetness of the sparkle of the city with all its spices like a laron approaching a torch which eventually destroys them. The condition of the child prostitution in Medan City has become apprehensive where many children aged 14-17 are involved in the prostitution business. Their involvement tends to be due to the factor of deception committed by collectors who work as collectors and suppliers of children to the prostitution places. This crime was committed in an organized manner as evidenced by the existence of syndicates that collaborated, ranging from child collectors and suppliers (collectors) and those who accommodate and employ children as the prostitutes (pimps / pimps), with recruitment areas covering malls, plazas, suburban areas, as well as other entertainment centers, which are generally the place where teenagers hang out.

In conclusion, the factors that cause organized crime against the child prostitution in Medan are environmental factors (there is good interaction and communication between them, both those from the same environment and those from different environments), economic

\footnotetext{
${ }^{1}$ Dosen Tetap Fakultas Hukum UMN Medan

${ }^{2}$ Fakultas Hukum UISU
}

factors and unemployment and which is very dominant is the psychological factor. The obstacles that are faced in overcoming organized crime against the child prostitution business are the obstacles in terms of legislation due to weaknesses rather than the scope of the law itself in ensnaring perpetrators of criminal acts of the child prostitution as well as the criminal threats which are still classified mild.

Keywords : Organized Crime, Child Prostitution, Criminal Psychology

\section{Abstrak}

Kejahatan yang dulunya banyak dilakukan oleh seorang diri sekarang banyak dilakukan oleh suatu kelompok-kelompok terorganisir dimana kekuatan hukum dari kelompok tersebut ilegal. pencurian, penodongan, penipuan, pembunuhan, korupsi, money loundry, pelacuran, terorisme merupakan beberapa bentuk kejahatan yang banyak dilakukan secara terorganisir.

Perkembangan dunia pelacuran anak telah tersebar di berbagai kota besar di Indonesia, tak terkecuali Medan. Gemerlapnya kota telah menarik banyak orang-orang yang berasal dari berbagai tempat di Indonesia maupun luar Indonesia ingin ikut mencicipi manisnya kegemerlapan kota dengan segala bumbunya bagaikan laron yang mendekati suluh yang akhirnya memusnahkan mereka. Kondisi pelacuran anak di Kota Medan sudah memprihatinkan dimana banyak anak usia 1417 tahun yang terlibat di dalam bisnis pelacuran tersebut. Keterlibatan mereka cenderung disebabkan faktor penipuan yang dilakukan oleh para kolektor yang bertugas sebagai pengumpul sekaligus pemasok anak-anak ke tempat pelacuran. Kejahatan ini dilakukan secara terorganisir yang dibuktikan dengan adanya sindikat yang bekerjasama, mulai dari pengumpul dan pemasok anak (kolektor) serta pihak yang menampung dan mempekerjakan anak sebagai pelacur (germo/mucikari), dengan daerah perekrutan yang meliputi Mall, Plaza, daerah pinggiran kota, serta pusat-pusat hiburan lain yang umumnya tempat gaul anak ABG.

Berdasarkan pembahasan maka diperoleh kesimpulan bahwa faktor-faktor yang menyebabkan kejahatan terorganisir terhadap pelacuran anak di kota Medan adalah faktor lingkungan (adanya interaksi dan komunikasi yang baik diantara mereka, baik yang berasal dari lingkungan yang sama maupun yang berasal dari lingkungan yang berbeda), faktor 
Media Komunikasi dan Informasi Hukum dan Masyarakat

ekonomi dan pengangguran dan yang sangat mendominasi adalah faktor psychology. Kendala-kendala yang dihadapi dalam mengatasi kejahatan terorganisir terhadap bisnis pelacuran anak adalah kendala dalam sudut perundang-undangan disebabkan faktor kelemahan daripada jangkauan undang-undang itu sendiri dalam menjerat pelaku tindak pidana pelacuran anak serta ancaman pidana yang masih tergolong ringan.

Kata Kunci : Kejahatan Terorganisir, Pelacuran Anak, Psikologi Kriminil

\section{PENDAHULUAN}

Sebagaimana diketahui bahwa manusia pada dasarnya tidak dapat hidup sendiri-sendiri melainkan manusia itu hidup selalu membutuhkan manusia yang lain, karena itulah manusia disebut makhluk sosial yang hidup bermasyarakat. $^{3}$

Seiring dengan manusia sebagai makhluk sosial, maka manusia tidak terlepas dari masalah-masalah kehidupan untuk meneruskan kehidupannya. Masalah manusia yang dihadapinya diantaranya adalah masalah kejahatan. Hal ini secara langsung dapat meresahkan masyarakat itu sendiri. Karena itu masalah kejahatan tidak terlepas dari kehidupan manusia itu sendiri.

Banyak bentuk kejahatan yang ada di kehidupan masyarakat pada umumnya dilakukan oleh dua orang atau lebih atau dilakukan secara terorganisir yang diikuti dengan tindakan-tindakan di luar perikemanusiaan seperti tindakan yang kejam dan sadir kepada korbannya. Adapun bentukbentuk kejahatan yang dilakukan secara terorganisir antara lain seperti pencurian, pemerkosaan, pembunuhan, penodongan, penipuan bahkan sampai kepada kejahatan yang sekarang ini masih hangat diperbicangkan

${ }^{3}$ Kartini Kartono, Pathologi Sosial, CV. Rajawali, Jakarta, 1991, h.143 oleh masyarakat dunia yakni kejahatan pelacuran anak dibawah umur dan berbagai macam kejahatan-kejahatan lainnya.

Masalah kejahatan merupakan suatu masalah sosial yang tidak dapat dilepaskan dari kehidupan sehari-hari. Masalah ini dapat dilihat dari berbagai media massa, baik melalui media cetak maupun media elektronik. Hampir tiap hari kejahatan itu terjadi seolah-olah kejahatan sudah menjadi budaya hidup manusia.

\section{Walaupun telah ada peraturan-} peraturan dengan ancaman hukuman yang berat tetapi masih ada juga orang yang melakukan kejahatan. Hal ini membuktikan bahwa hukuman yang berat bukanlah suatu ukuran yang dapat membuat penjahat menjadi jera atau membuat seseorang menghindari untuk berbuat kejahatan. Tegasnya hukuman dalam bentuk apapun yang ditimpakan kepada pelaku kejahatan tidak mempunyai pengaruh untuk mengurangi ataupun mencegah terjadinya kejahatan tersebut.

Kejahatan yang dulunya banyak dilakukan oleh seorang diri sekarang banyak dilakukan oleh suatu kelompok-kelompok terorganisir dimana kekuatan hukum dari kelompok tersebut ilegal. pencurian, penodongan, penipuan, pembunuhan, korupsi, money loundry, pelacuran, terorisme merupakan beberapa bentuk kejahatan yang banyak dilakukan secara terorganisir.

Kejahatan ini sering mengakibatkan terjadinya keresahan di dalam masyarakat. Bahkan hampir setiap hari kita melihat beritaberita tentang kejahatan di media elektronik maupuncetak yang tiada habisnya. Kejahatan merupakan masalah kehidupan yang erat kaitannya dengan perkembangan pemikiran, karena kejahatan merupakan pokok pemikiran 
Media Komunikasi dan Informasi Hukum dan Masyarakat

manusia yang diwujudkan dalam perilaku menyimpang.

\section{METODE PENELITIAN}

Penelitian ini tergolong sebagai penelitian hukum normatif. Data penelitian ini bersumber dari data sekunder yang bersumber dari bahanbahan hukum, yang terdiri dari bahan hukum primer, sekunder dan tersier. Penelitian ini menggunakan pendekatan undang-undang dan pendekatan konseptual. Analisis data dalam penelitian ini menggunakan analisis data kualitatif.

\section{HASIL DAN PEMBAHASAN}

\section{A. Gambaran Umum Tentang Kejahatan}

Kejahatan adalah merupakan

persoalan yang dialami manusia dari waktu ke waktu. Mengapa kejahatan terjadi dan bagaimana pemberantasannya, merupakan persoalan yang tiada hentinya diperdebatkan. "Kejahatan merupakan problema manusia. Karena itu dimana ada manusia maka di sana pasti ada kejahatan (Crime is eternal as eternal as society)".

Sedangkan menurut WA. Bonger menyebutkan bahwa kejahatan adalah "suatu perbuatan yang melanggar norma hukum yang oleh negara ditentang dengan sadar dengan penjatuhan hukuman atau dapat dikenakan sanksi pidana". ${ }^{12}$

Di dalam perumusan pasal-pasal KUHPidana jelas tercantum bahwa kejahatan adalah "semua bentuk perbuatan yang memenuhi perumusan ketentuan-ketentuan KUHPidana”. ${ }^{13}$
Dengan demikian secara yuridis formal, kejahatan adalah bentuk tingkah laku yang melanggar Undang-Undang Hukum Pidana.

Menurut Kartini Kartono bahwa secara sosiologis kejahatan adalah :

Semua bentuk ucapan, perbuatan dan tingkah laku yang secara ekonomis, politis dan sosial pskihologis sangat merugikan masyarakat, melanggar norma-norma susila dan menyerang keselamatan warga masyarakat (baik yang telah tercakup dalam Undang-Undang maupun yang belum tercantum dalam Undang-Undang Pidana). ${ }^{14}$

Tingkah laku manusia yang jahat, immoril dan anti sosial itu banyak menimbulkan reaksi kemarahan di kalangan masyarakat dan jelas sangat merugikan umum. Karena itu kejahatan tersebut harus diberantas atau tidak boleh dibiarkan berkembang, demi ketertiban, keamanan dan keselamatan masyarakat. Maka masyarakat secara keseluruhan, bersama-sama dengan lembaga-lembaga resmi yang berwenang (Kepolisian, Pengadilan, kejaksaan dan lembaga pemasyarakatan dan lain-lain) wajib menanggulangi kejahatan.

Menurut B. Simanjuntak, kejahatan itu dibagi atas tiga jenis pengertian yaitu :

1. Pengertian secara praktis bahwa kejahatan adalah pelanggaran atas norma-norma agama, kebiasaan, kesusilaan yang hidup dalam masyarakat.

2. Kejahatan dalam arti secara religious adalah pelanggaran atas perintah-perintah Tuhan. Pengertian a dan b dapat disebut pengertian kriminologis.

3. pengertian secara yuridis bahwa kejahatan adalah setiap perbuatan atau pelalaian yang dilarang oleh hukum publik untuk melindungi masyarakat dan diberi pidana oleh negara. ${ }^{15}$
12 WA. Bonger., Pengantar Tentang Kriminologi, PT. Pembangunan Ghalia Indonesia, 1977, h.21.

${ }^{13}$ Kartini Kartono., Op.Cit, h.147.

\footnotetext{
${ }^{14}$ Ibid., h.148.

15 B. Simanjuntak., Pengantar Psikologi Kriminal, Tarsito, Bandung, 1991, h.52.
} 
Media Komunikasi dan Informasi Hukum dan Masyarakat

Menurut Kartini Kartono menyebutkan

bahwa "kriminalitas atau kejahatan itu bukan merupakan peristiwa bawaan sejak lahir, warisan, juga bukan merupakan warisan biologis". 16

Tingkah laku kriminal itu bisa dilakukan oleh siapapun juga, baik wanita maupun pria, dapat berlangsung pada usia anak, dewasa ataupun lanjut umur. Tindak kejahatan itu dapat dilakukan secara sadar yaitu dipikirkan, direncanakan dan diarahkan pada satu maksud tertentu secara sadar benar. Namun dapat juga dilakukan secara setengah sadar, misalnya didorong oleh impuls-impuls yang hebat, didera oleh dorongan-dorongan paksaan yang sangat kuat (kompulsi-kompulsi) dan oleh obsesiobsesi. Kejahatan dapat juga dilakukan secara tidak sadar sama sekali. Misalnya karena terpaksa untuk mempertahankan hidupnya, seseorang harus melawan dan terpaksa membalas menyerang, sehingga terjadi peristiwa pembunuhan.

Masyarakat modern yang sangat kompleks itu menumbuhkan aspirasiaspirasi materil tinggi dan sering disertai oleh ambisi-ambisi sosial yang tidak sehat. Dambaan pemenuhan kebutuhan materil yang melmpah-limpah misalnya untuk memiliki harta kekayaan dan barang-barang mewah tanpa mempunyai kemampuan untuk mencapainya dengan jalan wajar, mendorong individu untuk melakukan tindak kriminal. Dengan kata lain dapat disebutkan bahwa jika terdapat diskrepansi (ketridak sesuaian, pertentangan) antara ambisi-ambisi dengan kemampuan pribadi, maka peristiwa sedemikain ini mendorong orang untuk melakukan tindak kriminal. Atau jika terdapat diskrepansi antara aspirasiaspirasi dengan potensi-potensi personal, maka akan terjadi maladjustment ekonomis (ketidak mampuan menyesuaikan diri secara ekonomis) yang mendorong orang untuk bertindak jahat atau melakukan tindak pidana. ${ }^{17}$

Secara yuridis formal, kejahatan adalah "bentuk tingkah laku yang bertentangan dengan moral kemanusiaan (immoril), merugikan masyarakat, a-sosial sifatnya dan melanggar hukum serta Undang-undang Pidana". ${ }^{18}$

Di dalam perumusan pasal-pasal Kitab Undang-Undang Hukum Pidana jelas tercantum bahwa kejahatan adalah semua bentuk perbuatan yang memenuhi perumusan ketentuan-ketentuan KUH Pidana, Misalnya pembunuhan adalah perbuatan yang memenuhi perumusan Pasal 338 KUHP, mencuri memenuhi bunyi Passal 362 KUHP, sedangkan kejahatan penganiayaan memenuhi Pasal 351 KUHP.

Banyak para sarjana yang membuat pengertian mengenai kejahatan terorganisir sebagaimana dikutip oleh Nurmalawaty yaitu antara lain menurut :

1. Donald Cressey.

Kejahatan terorganisir sebagai sesuatu kejahatan yang mempercayakan penyelenggaraannya pada seseorang, yang mana dalam mendirikan pembagian kerjanya bertujuan merencanakan misi kejahatan secara lengkap seperti : pembagian kerja, yang sedikit di dalamnya terdapat seorang penaksir, pengumpul dan seorang pemaksa.

2. Michael Maltz.

Kejahatan terorganisir didefenisikan sebagai suatu kejahatan yang dilakukan lebih dari satu orang, yang memiliki kesetian terhadap perkumpulannya untuk tujuan menyelenggarakan kejahatan. Ruang lingkup dari kejahatan itu meliputi kekejaman, pencuruan, korupsi, monopoli ekonomi, penipuan dan menimbulkan korban.

3. Frank Hagan.

Kejahatan terorganisir adalah sekumpulan orang yang memulai aktivitas kejahatannya

17 Ibid, h.143-144

18 Ibid., h.147. 
Media Komunikasi dan Informasi Hukum dan Masyarakat

dengan melibatkan diri pada pelanggaran hukum untuk mencari keuntungan secara ilegal dengan menyediakan kekuatan ilegal dan mengikatkan aktivitasnya pada kegiatan pemerasan dan penyelewengan keuangan. ${ }^{19}$

Dari ketiga defenisi yang dikemukakan para sarjana tersebut di atas, dapat dilihat bahwa kejahatan terorganisir ini mempunyai defenisi dan ruang lungkup kejahatannya yang cukup luas. Kegiatannya meliputi pelacuran, perjudian, perdagangan gelap, pemberian jasa gelap, bank gelap dan masih banyak jasa lainnya.

\section{B. Gambaran Tentang Pelacuran}

Sebagaimana diketahui bahwa pelacuran itu bisa dilakukan oleh kaum wanita maupun pria. Jadi ada persamaan predikat lacur antara laki-laki dan wanita yang bersama-sama melakukan perbuatan hubungan kelamin di luar perkawinan. Dalam hal ini perbuatan cabul tidak hanya berupa hubungan kelamin di luar nikah saja, akan tetapi termasuk pula peristiwa homoseksual dan permainan-permainan seksual lainnya.

Menurut Kartini Kartono menyebutkan bahwa prostitusi adalah "bentuk penyimpangan seksual dengan pola-pola organisasi impuls atau dorongan seks yang tidak wajar dan tidak terintegrasi dalam bentuk pelampiasan nafsunafsu seks tanpa kendali dengan banyak orang disertai eksploitasi dan komersialisasi seks yang impersonal tanpa afeksi sifatnya". ${ }^{22}$

\section{W.A. Bonger (dikutip oleh Sudarsono)} dalam tulisannya "Maatschappelijke Oorzaken der Prostitue" menulis definisi sebagai berikut "Prostitusi ialah gejala kemasyarakatan dimana

${ }^{19}$ Nurmalawati., Kriminologi, FH. Universitas Diponegoro, Semarang, 2000, h,9

${ }^{22}$ Kartini Kartono., Op.Cit, h.211. wanita menjual diri melakuakan perbuatanperbuatan seksual sebagai mata pencaharian". ${ }^{23}$

Pada definisi ini jelas dinyatakan adanya peristiwa penjualan diri sebagai "profesi" atau mata pencaharian sehari-hari, dengan jalan malakukan relasi-relasi seksual. Nini Widiyanti menyatakan bahwa "prostitusi adalah penyerahan diri dari wanita kepada banyak lakilaki dengan pembayaran". ${ }^{24}$

Definisi di atas mengemukakan adanya unsur-unsur ekonomis, dan penyerahan diri wanita yang dilakukan secara berulang-ulang atau terus-menerus dengan banyak laki-laki.

Dengan demikian pelacur atau yang sekarang ini lebih populer dengan sebutan pekerja seks komersial adalah wanita yang mempunyai kebiasaan melakukan hubungan kelamin di luar pernikahan, baik dengan imbalan jasa maupun tidak. Dengan perkataan lain bahwa pekerja seks komersial,adalah mereka yang biasa melakukan hubungan kelamin di luar pernikahan yang syah.

Jelasnya, pelacuran itu bisa dilakukan baik oleh kaum wanita maupun pria. Jadi, ada persamaan "predikat lacur" antara laki-laki dan wanita yang bersama-sama melakukan perbuatan kelamin di luar perkawinan. Dalam hal ini perbuatan cabul tidak hanya berupa hubungan kelamin di luar nikah saja, akan tetapi termasuk pula peristiwa homoseksual dan permainan-permainan seksual lainnya.

G. May (dikutip oleh Kartini Kartono) menyebutkan bahwa masalah prostitusi sebagai berikut :

Prostitution defined as sexual intercourse characterized by barter, promiscuity and emotional indifference.

${ }^{23}$ Sudarsono., Kenakalan Remaja, Rineka Cipta, Jakarta, 1990, h.17

24 Nini Widiyanti dan Panji Anoroga., Perkembangan Kejahatan dan Masalahnya, Pradnya Paramitra, Jakarta, 1992, h.11. 
May menekankan masalah barter atau perdagangan secara tukar-menukar; yaitu menukarkan pelayanan seks dengan bayaran uang, hadiah atau barang berharga lainnya. Juga mengemukakan promiskuitas, yaitu hubungan seks bebas, benda-benda, materi dan uang. Maka dalam pelacuran ini ada pelampiasan nafsu-nafsu seks secara bebas dengan banyak pria, atas perjanjian pemberian "keuntungan" pada kedua belah pihak (para pelaku). ${ }^{25}$

Selanjutnya, perbuatan melacurkan diri ini dilakukan baik dalam sambilan atau pengisi waktu senggang (amateurisme), maupun sebagai pekerjaan penuh atau profesi.

Pekerja seks komersial wanita disebut dalam bahasa asingnya prostitue, sedang penamaan kasarnya ialah : sundal, balon ataupun lonte.

Pada tahun-tahun 60-an oleh beberapa pihak terutama para petugas Dinas Sosial, menggunakan istilah eufemistis untuk memperhalus artinya, ialah : wanita tuna susila. Sedang pelacur pria disebut gigolo.

Dengan adanya unsur komersialisasi dan barter seks (perdagangan tukar-menukar seks dengan benda bernilai), maka pelacuran merupakan profesi yang paling tua sepanjang sejarah kehidupan manusia.

Dimaksud dalam kategori pelacuran ini antara lain ialah :

a. Pergundikan yaitu pemeliharaan bini tidak resmi, bini gelap atau perempuan piaraan. Mereka hidup sebagai suami istri, namun tanpa ikatan perkawinan. Gundik-undik orang asing ini pada zaman pemerintahan Belanda dahulu disebut nyai.

b. Tante girang atau loose married women yaitu wanita yang sudah kawin, namun tetap melakukan hubungan erotik dan seks dengan laki-laki lain, baik secara iseng untuk mengisi waktu kosong, bersenangsenang "just for fun" dan mendapatkan pengalaman-pengalaman seks lain maupun

${ }^{25}$ Kartini Kartono., Psikologi Abnormal dan Pathologi Seks, Alumni,Bandung, 1990, h.69. secara intensional untuk mendapatkan penghasilan.

c. Gadis-gadis panggilan ialah gadis-gadis dan wanita-wanita biasa yang menyediakan diri untuk dipanggil dan dipekerjakan sebagai prostitue, melalui saluran-saluran tertentu. Mereka ini terdiri atas ibu-ibu rumah tangga, pelayan-pelayan toko, pegawai-pegawai buruh-buruh perusahaan, gadis-gadis sekolah lanjutan, para mahasiswi, dan lain-lain.

d. Gadis-gadis bar atau B-girl yaitu gadisgadis yang bekerja sebagai pelayanpelayan bar, dan sekaligus bersedia memberikan pelayanan seks kapada para pengunjung.

e. Gadis-gadis juvinile atau B-girl yaitu gadisgadis muda dan jahat, yang didorong oleh ketidak matangan emosinya dan retardasi/keterbelakangan inteleknya, menjadi sangat pasif dan sugestibel sekali. Karakternya sangat lemah. Sebagai akibatnya, mereka itu mudah sekali jadi pencandu obat-obat bius (ganja, heroin, morfin, dan lain-lain), sehingga mudah tergiur melakukan perbuatan-perbuatan immoril seksual dan pelacuran.

f. Gadis-gadis binal atau free girl yaitu gadisgadis sekolah atau putus sekolah (putus studi di akademi atau fakultas) yang menyebar luaskan kebebasan seks secara ekstrim, untuk mendapatkan kepuasan seksual. Mereka menganjurkan sek bebas dan cinta bebas.

g. Gadis-gadis taxi-girl, yaitu wanita-wanita dan gadis-gadis panggilan yang ditawartawarkan dan dibawa ke tempat "plesiran" dengan taksi-taksi atau becak.

h. Penggali emas atau gold-diggers yaitu gadis-gadis dan wanita-wanita cantik, raturatu kecantikan, pramugari, penyanyi, pemain bintang film, pemain sandiwara teater atau opera, anak wayang, dan lainlain yang pandai merayu dan bermain cinta, untuk mengeduk kekayaan orangorang berduit. Pada umumnya, sulit sekali orang itu diajak bermain seks. Yang diutamakan oleh mereka adalah : dengan keahliannya menggali emas dan kekayaan dari para "kekasihnya".

i. Hostess atau pramuria yang menyemarakkan kehidupan malam dalam nightclub. Pada intinya, profesi hostess merupakan bentuk pelacuran halus. Sedang pada intinya, "hostess" itu adalah predikat baru dari pelacuran. Sebab, di lantai-lantai dansa mereka itu membiarkan diri dipeluki, diciumi, dan diraba-raba seluruh badannya. Juga di meja-meja minum badannya diraba-raba dan diremas- 
Media Komunikasi dan Informasi Hukum dan Masyarakat

remas oleh langganan. Para hostess ini harus melayani makan, minum, dansa, dan memuaskan naluri-naluri seks para langganan dengan jalan "menikmati tubuh" para hostess atau pramuria tersebut. Dengan demikian langganan bisa menikmati keriaan atau kesenangan suasana tempat-tempat hiburan. ${ }^{26}$

\section{Faktor-Faktor Yang Menyebabkan Kejahatan Terorganisir Terhadap Pelacuran Anak Di Kota Medan}

Masalah kejahatan merupakan suatu masalah sosial yang tidak dapat dilepaskan dari kehidupan kita sehari-hari. Masalah ini dapat kita dilihat dari berbagai media massa, baik melalui media cetak maupun media elektronik. Hampir tiap hari kejahatan itu terjadi seolah-olah kejahatan sudah menjadi budaya hidup manusia.

Walaupun telah ada peraturanperaturan dengan ancaman hukuman yang berat tetapi masih ada juga orang yang melakukan kejahatan. Hal ini membuktikan bahwa hukuman yang berat bukanlah suatu ukuran yang dapat membuat penjahat menjadi jera atau membuat seseorang menghindari untuk berbuat kejahatan. Tegasnya hukuman dalam bentuk apapun yang ditimpakan kepada pelaku kejahatan tidak mempunyai pengaruh untuk mengurangi ataupun mencegah terjadinya kejahatan tersebut.

Kejahatan yang dulunya banyak dilakukan oleh seorang diri sekarang banyak dilakukan oleh suatu kelompok-kelompok terorganisir dimana kekuatan hukum dari kelompok tersebut ilegal. pencurian, penodongan, penipuan, pembunuhan, korupsi, money loundry, pelacuran, terorisme merupakan beberapa bentuk kejahatan yang banyak dilakukan secara terorganisir.
Balakangan ini para pejabat negara serta aparat penegak hukum sudah bekerja keras memikirkan lebih mendalam dan secara ilmiah bagaimana mengatasi dan mencegah agar tidak terjadi kejahatan terorganisir tersebut. Namun persoalan mencari solusi ini bukanlah hal yang mudah untuk menemukannya disebabkan ada beberapa faktor yang sangat berpengaruh sekali yang mendorong orangorang tersebut untuk melakukan kejahatan secara terorganisir, yang mana faktor-faktor tersebut dianggap sangat sulit untuk diatasi.

Menurut hasil wawancara penulis dengan IPTU Zufri Siregar, Kepala Urusan Pembinaan Operasi Sat Serse Polresta Medan menyebutkan bahwa ada beberapa prilaku di dalam kehidupan masyarakat yang dapat mengarahkan kepada masalah kejahatan terorganisir, antara lain sebagai berikut:

1. Biasanya anggota-anggota dari kelompok tersebut adalah orang-orang yang tidak mempunyai pekerjaan dan senang berkumpul-kumpul kemudian membuat suatu kelompok yang sifatnya tidak terbimbing, yang mana pada akhirnya kelompok tersebut membuat suatu rencana untuk melakukan kejahatan.

2. Mereka biasanya pengguna obat-obatan terlarang ataupun mempunyai ketergantungan terhadap alkohol, sehingga mengakibatkan suatu dorongan jiwa yang tidak terkendali, yang pada akhirnya karena keadaan jiwa tersebut maka timbul dorongan untuk dapat selalu memenuhi kebutuhan tersebut.

3. Adanya interaksi atau komunikasi antara mereka yang baik, baik di dalam lingkungan yang sama maupun dari lingkungan yang berbeda, dimana mereka ini sama-sama tidak mempunyai suatu kegiatan atau pekerjaan sehingga akhirnya mereka menggabungkan diri dan membentuk suatu kelompok yang sifatnya tidak baik/jahat. ${ }^{33}$
33 Hasil Wawancara Dengan Zufri Siregar Kepala Urusan Pembinaan Operasi Sat Serse Polresta Medan Tanggal 23 Mei 2013 
Media Komunikasi dan Informasi Hukum dan Masyarakat

Adapun faktor-faktor yang mendorong sehingga lebih cenderung untuk melakukan kejahatan terorganisir adalah disebabkan karena :

1. Lebih bersemangat dan lebih berani. Hal ini sudah jelas bahwa perasaan takut akan berkung apabila melakukan secara terorganisir dibandingkan melakukan secara sendirian.

2. Lebih mudah dalam pelaksanaannya, karena dilakukan secara bersama-sama dan pekerjaannya lebih cepat selesai.

3. Lebih mudah untuk dapat berbuat lebih kejam. Para pelaku dari kejahatan terorganisir sering berperilaku lebih kejam dan sadis serta di luar perikemanusiaan.. $^{34}$

Berdasarkan hasil penelitian yang penulis lakukan, maka dapat diketahui beberapa faktor utama yang mempengaruhi terjadinya kejahatan terorganisir :

\section{Pengangguran dan ekonomi.}

Kejahatan akan meningkat apabila pengangguran bertambah. Secara logika hal tersebut sangat benar, sebab para penganggur itu dengan cara bagaimanapun tentu akan berusaha mencapai kebutuhankebutuhan hidupnya baik dengan jalan yang legal maupun illegal, sehingga hal ini yang mendorong meningkatnya kejahatankejahatan terhadap harta kekayaan dan mungkin pula diikuti kejahatan dengan kekerasan seperti pembunuhan, perampokan, penodongan dan lain-lain.

Masalah pengangguran ini memang merupakan masalah yang sangat sulit untuk ditanggulangi pada masa sekarang ini terutama di negara-negara yang sedang berkembang. Bertambahnya

34 Hasil Wawancara Dengan Zufri Siregar Kepala Urusan Pembinaan Operasi Sat Serse Polresta Medan Tanggal 23 Mei 2013 angka pengangguran ini disebabkan oleh faktor-faktor sebagai berikut :

1. Pertambahan penduduk yang cepat, yang mana hal ini disebabkan tingginya angka kelahiran, menurunnya angka kematian. Dewasa ini angka kematian menurun disebabkan oleh kemajuankemajuan dalam ilmu kedokteran.

2. Pertambahan penduduk yang tinggi tidak dapat diimbangi oleh penyediaan lapangan kerja, sehingga setiap tahun angka pengangguran ini akan tetap bertambah. $^{35}$

Bila angka pengangguran tetap bertambah, maka hal ini berakibat seruis terhadap negara yang bersangkutan, sebab jika jumlah pengangguran makin meningkat maka akan meningkat pulalah ketegangan sosial di dalam masyarakat dan ketertiban hukum akan terganggu, sebab para penganggur itu juga adalah manusia yang biasa. Dimana mereka memerlukan makanan, minuman, pakaian dan lain-lain, yang bila tidak dapat diperoleh secara halal dan wajar, tentu mereka melakukan perbuatan-perbuatan yang melanggar hukum seperti mencuri, merampok, membunuh dan lain-lain yang mengakibatkan tidak adanya ketentraman di dalam masyarakat.

"Demikian juga apabila keadaan ekonomi tidak stabil, dimana pada masa ini Indonesia mengalami krisis ekonomi dan tidak tetapnya nilai tukar dolar terhadap rupiah, maka hal ini juga merupakan salah satu faktor yang dapat menimbulkan kejahatan, baik dari segi kwalitas maupun dari segi kwantitasnya". ${ }^{36}$

Pada umumnya orang-orang miskin lebih cenderung melakukan kejahatan ekonomi

\footnotetext{
35 Hasil Wawancara Dengan Zufri Siregar Kepala Urusan Pembinaan Operasi Sat Serse Polresta Medan Tanggal 23 Mei 2013

36 Hasil Wawancara Dengan Zufri Siregar Kepala Urusan Pembinaan Operasi Sat Serse Polresta Medan Tanggal 23 Mei 2013
} 
Media Komunikasi dan Informasi Hukum dan Masyarakat

seperti pencurian dan perampokan. Tetapi bukan berarti orang-orang kaya tidak melakukan pencurian seperti apa yang dikatakan oleh Zufri Siregar Kepala Urusan Pembinaan Operasi Sat Serse Polresta Medan Tanggal 23 Mei 2013 yaitu "Kejahatan yang besar tidak diperbuat untuk memperoleh apa yang perlu untuk hidup, tetapi untuk kemewahan".37

Dari penjelasan di atas maka jelaslah bahwa faktor pengangguran dan ekonomi sangat berpengaruh terhadap terjadinya kejahatan termasuk kejahatan yang terorganisir. Pada umumnya anggota-anggota atau pelaku kejahatan terorganisir ini mempunyai latar belakang ekonomi yang kurang baik sementara kebutuhan hidup selalu bertambah, mereka menganggap melakukan kejahatan contohnya dengan melakukan perampokan merupakan satu-satunya solusi yang cepat, tepat, dan efisien untuk dapat memenuhi segala kebutuhan hidupnya meskipun pekerjaan tersebut beresiko tinggi.

\section{Lingkungan Masyarakat.}

Lingkungan sangat menentukan terhadap prilaku seseorang, demikian kuatnya pengaruh lingkungan itu sehingga semestinyalah lingkungan yang lebih bertanggung jawab terhadap bagaimana jadinya manusia itu dari pada manusia itu sendiri.

Ada berbagai macam jenis lingkungan ini, tetapi dalam pembahasan skripsi ini penulis hanya membatasi pada lingkungan masyarakat saja. Karena menurut pengamatan penulis, bahwa kejahatan yang dilakukan terorganisir erat sekali hubungannya dengan lingkungan masyarakat yang buruk. Kalau keadaan ekonomi kita saat ini mengalami resesi, maka

37 Hasil Wawancara Dengan Zufri Siregar Kepala Urusan Pembinaan Operasi Sat Serse Polresta Medan Tanggal 23 Mei 2013 lingkungan kehidupan masyarakat Indonesia sekarang juga dalam masa resesi.

Pada umumnya setiap lingkungan masyarakat menyebarkan atau menularkan bibit-bibit yang tidak baik terhadap sesamanya. Contohnya seorang anak yang hidup di dalam keluarga yang baik-baik, kalau ia bergaul ke luar rumah atau lingkungan yang mempunyai potensi untuk timbulnya kejahatan maka hal tersebut akan mempengaruhi tingkah laku anak tersebut. Akibat pergaulan di luar rumah tersebut, maka si anak tadi akan membawa sikap yang lain dari biasanya sewaktu ia masih di rumah. Hal ini membuat para orang tua khawatir terhadap anaknya dan sering membuat para orang tua bingung memikirkan masalah pergaulan anaknya.

Namun sebaliknya apabila anak yang dikungkung di rumah saja bisa membuat pengaruh yang tidak baik bagi perkembangan jiwa si anak tersebut. Si anak tidak di beri kebebasan dalam mencari teman pergaulannya. $\mathrm{Hal}$ inilah yang menjadi polemik bagi orang tua.

Akibat dari lingkungan masyarakat yang tidak baik menimbulkan beberapa kelompok yang sering melakukan kejahatan didalam masyarakat, dalam perkataan sehari-hari disebut dengan preman atau geng-geng.

"Banyak kelompok-kelompok yang dibentuk sekarang ini tidak bersifat mendidik. Malah kelompok-kelompok yang frustasi tersebar di hampir setiap persimpangan jalan dan tempat-tempat kumuh atau masyarakatnya rata-rata dibawah garis kemiskinan." ${ }^{38}$

Memang sudah merupakan naluri manusia untuk berkumpul dan bergaul dengan teman-temannya. Tetapi pergaulan akan menimbulkan efek yang baik dan yang tidak baik pula, efek yang

38 Hasil Wawancara Dengan Zufri Siregar Kepala Urusan Pembinaan Operasi Sat Serse Polresta Medan Tanggal 23 Mei 2013 
Media Komunikasi dan Informasi Hukum dan Masyarakat

tidak baik akan mendorong si anak terjerumus kepada yang tidak mendapat bimbingan dari orang tua dan tidak memperdulikan orang tuanya lagi. Sebab pergaulan yang tidak baik ini, maka seseorang mempunyai prilaku yang kurang baik seperti biasa merokok, terlibat narkotika dan sering membuat keributankeributan yang pada akhirnya mengakibatkan terganggunya ketertiban masyarakat umum. ${ }^{39}$

Karena pengaruh lingkungan yang tidak terkendalikan oleh perkembangan jiwa, hal inilah membuat kecenderungan seseorang untuk berprilaku lebih jahat lagi.

Jadi jelaslah bahwa faktor lingkungan juga memegang peranan dalam mempengaruhi atau mendorong seseorang untuk berprilaku lebih jahat atau brutal. Faktor lingkungan ini merupakan faktor yang paling dominan terhadap kejahatan yang dilakukan terorganisir karena di dalam lingkungan masyarakat ini, terdapat interaksi dan komunikasi yang sangat kompleks.

Sehingga sangat gampang dan cepat terjadi saling pengaruh mempengaruhi antar sesama individu untuk melakukan kejahatan.

\section{Media Massa Atau Kemajuan Tekhnologi}

Sarana mass media sebagai perkembangan tekhnologi merupakan salah satu faktor yang berpengaruh terhadap terjadinya kejahatan termasuk bentuk kejahatan yang dilakukan secara terorganisir, salah satu contoh yaitu tayangan film dan siaran televisi pada masa sekarang ini dianggap masyarakat umum merupakan salah satu penyebab timbulnya kejahatan, karena film dan televisi khususnya lebih banyak dikambing hitamkan masyarakat sebagai sumber kejahatan dari

39 Hasil Wawancara Dengan Zufri Siregar Kepala Urusan Pembinaan Operasi Sat Serse Polresta Medan Tanggal 23 Mei 2013 pada dianggap sebagai medium seni dan pendidikan. Pikiran sehat mengatakan bahwa film dan televisi itu mempunyai pengaruh yang besar sekali terhadap perkembangan psikologis orang yang menontonnya. Misalnya dengan menonton adegan film yang berkenaan dengan kejahatan seperti pencurian dan perampokan, disitu si penonton pasti mempunyai pikiran bahwa betapa mudahnya memenuhi kebutuhan hidup tanpa melakukan pekerjaan yang sah.

Bahwa salah satu sebab-sebab kejahatan itu bersumber dari film karena penonton (sebagian orang pada umumnya meniru prilaku yang telah ditayangkan di layar bioskop dan televisi. Tetapi ada berbagai pendapat orang, yang mengatakan bahwa film itu penting karena film ini dapat berbagai cara orang untuk mengambil faedah dari hasil-hasil film yang dipertunjukkan, tetapi pada umumnya kebanyakan film-film yang diputar di panggung bioskop atau PHR itu yang dapat merusak mental anak-anak. Sebagai contoh dapat kita lihat dewasa ini para pengusaha bioskop umumnya bertujuan untuk mencari keuntungan semata-mata tanpa membatasi umur berapakah yang dapat menonton film tersebut. ${ }^{40}$

Hal ini sering terjadi bahwa film untuk usia 17 tahun ke atas dapat ditonton oleh anakanak yang belum berusia 17 tahun. Jadi hal inilah yang dapat merusak mental si anak tanpa memikirkan akibatnya bagi masyarakat terutama generasi muda sebagai penerus cita-cita bangsa. Untuk itu pada benak penulis terkandung suatu pertanyaan : Apakah hal ini tidak ada unsur-unsur kesengajaan dari si pengusaha bisnis perfilman yang pada umumnya kurang kesadarannya terhadap kepentingan nasional demi kelanjutan generasi

40 Hasil Wawancara Dengan Zufri Siregar Kepala Urusan Pembinaan Operasi Sat Serse Polresta Medan Tanggal 23 Mei 2013 
Media Komunikasi dan Informasi Hukum dan Masyarakat

penerus dan semata-mata hanya melihat kepentingan materialnya saja.

Dari uraian tersebut jelaslah bahwa pengaruh film dan televisi bukanlah suatu kepastian untuk membuat seseorang menjadi jahat, tetapi faktor media massa khususnya film dan televisi merupakan faktor pendorong dan dapat mengarahkan seseorang menjurus kepada prilaku prilaku yang jahat.

\section{Faktor Psikologis}

Mengenai faktor-faktor psychologis yang mendorong dilakukannya kejahatan terorganisir pada dasarnya sangat kompleks sekali. Masalahnya terletak pada luasnya gerak ruang lingkup kehidupan manusia, yang saling berhubungan dan saling mempengaruhi serta saling kait satu sama lainnya. Seperti diketahui pada masa progressif, manusia mengalami 2 (dua) kali masa krisis, dimana pada masa krisis 1 (pertama) merupakan masa penentuan secara positif maupun negatif.

\section{Kendala Yang Dihadapi Polresta Medan Dalam Mengatasi Kejahatan Terorganisir Terhadap Pelacuran Anak}

Sebagai negara berkembang, Indonesia belum dapat melangkah maju mencapai satu tahap awal untuk memprakarsai suatu perencanaan yang bersifat konstruktif di bidang kebijakan anti perdagangan dan pelacuran anak. Langkah proses penegakan hukum di Indonesia pun masih tergolong lemah.

Secara konsepsional dapat dikatakan bahwa inti dari penegakan hukum terletak pada kegiatan menyerasikan hubungan nilai-nilai yang terjabarkan di dalam kaedah-kaedah yang mantap dengan mengedepankan sikap tindak sebagai rangkaian penjabaran nilai tahap akhir untuk menciptakan memelihara dan mempertahankan kedamaian pergaulan hidup. ${ }^{43}$

Masalah penegakan hukum sendiri dalam pelaksanaannya dipengaruhi oleh lima faktor. Menurut Soerjono Soekantor, kelima faktor tersebut, yaitu :

1. Faktor hukum itu sendiri yang bertumpu pada Undang-undang

2. Faktor penegak hukum, yakni pihak-pihak yang membentuk maupun menerapkan hukum.

3. Faktor sarana atau fasilitas yang mendukung penegakan hukum

4. Faktor masyarakat, yakni dimana hukum tersebut berlaku dan diterapkan

5. Faktor kebudayaan, yakni sebagai hasil karya, cipta dan rasa yang didasarkan pada karsa manusia di dalam pergaulan hidup. ${ }^{44}$

Kondisi pelacuran anak di Indonesia pada umumnya dan di kota Medan pada khususnya sudah sangat memprihatinkan. Banyak anak usia remaja yang terlibat dalam dunia pelacuran. Ironisnya, keterlibatan mereka justru kebanyakan akibat perbuatan para kolektor yang memasok mereka ke bisnis prostitusi anak melalui berbagai modus operandi seperti menjanjikan pekerjaan dengan gaji yang besar, serta segudang alasan lainnya.

\section{KESIMPULAN}

Faktor-faktor yang menyebabkan kejahatan terorganisir terhadap pelacuran anak di kota Medan adalah faktor lingkungan (adanya interaksi dan komunikasi yang baik diantara mereka, baik yang berasal dari lingkungan yang sama maupun yang berasal dari lingkungan yang berbeda), faktor ekonomi dan pengangguran dan yang sangat mendominasi adalah faktor psychologi.

43 Soerjono Soekanto, Faktor-faktor Yang Mempengaruhi Penegakan Hukum, Raja Grafindo Persada, Jakarta, 2002, h. 3.

${ }^{44} \mathrm{Ibid}$, h.5. 
Media Komunikasi dan Informasi Hukum dan Masyarakat

Kendala yang dihadapi Polresta Medan dalam mengatasi kejahatan terorganisir terhadap pelacuran anak adalah sebagai berikut :

a. Kendala dalam sudut perundang-undangan disebabkan faktor kelemahan daripada jangkauan undang-undang itu sendiri dalam menjerat pelaku tindak pidana pelacuran anak serta ancaman pidana yang masih tergolong ringan. Hal lain juga dikarenakan belum adanya Undang-undang yang khusus mengatur tentang masalah tindak pidana pelacuran anak.

b. Kendala pada sisi kinerja dari aparat penegak hukum cenderung disebabkan aparat penegak hukum itu sendiri yang kurang mengerti mengenai masalah pelacuran anak di samping faktor terbesar adalah karena ternyata banyak anggota dari aparat penegak hukum itu sendiri yang terlibat dalam bisnis pelacuran ini melalui sistem beking.

c. Sedangkan dari sisi kondisi pandangan budaya masyarakat lebih disebabkan oleh sikap ketidakpedulian masyarakat itu sendiri yang cenderung bersikap masa bodoh dalam melihat fenomena pelacuran anak yang ada di hadapan mereka, di samping ada juga sebagian kecil masyarakat yang ternyata melegalkan anaknya untuk menjadi pelacur guna membantu ekonomi keluarga.

\section{DAFTAR BACAAN}

B. Simanjuntak., Pengantar Kriminologi dan Pathologi Sosial, Tarsito, Bandung, 1992.

Pengantar Psikologi Kriminal, Tarsito, Bandung, 1991.

Barda Nawawi Arif, Bunga Rantai Kebijakan Hukum Pidana, Citra Aditya Bakti, Bandung, 1996.

Chainur Arrasyid., Suatu Pemikiran Tentang Psikologi Kriminil, FH.USU, Medan, 1999

Harkristuti Harkrisnowo., Proses Pembuktian dan Pertanggung Jawaban Pidan Koorporasi Dalam Tindak Pidana, FH. UI, Jakarta, 2001

Kartini Kartono, Pathologi Sosial, CV. Rajawali, Jakarta, 1991.

;Psikologi Abnormal dan Pathologi Seks, Alumni,Bandung, 1990

Maulana Hasan Wadong., Pengantar Advokasi dan Hukum Perlindungan Anak, Gramedia Widiasarana Indonesia, Jakarta, 2000.

Made Darma Weda., Kriminologi, PT. Raja Grafindo Persada, Jakarta, 1996.

Manida Naebklang., dit.ol., Ramlan, dan et.ol., Irwanto, Tanya \& Jawab Tentang Eksploitasi Seksual Komersial Anak Sebuah Buku Saku Informasi Oleh ECPAT Internasional, Restu PrintingIndonesia, Jakarta, 2006

Nini Widiyanti dan Panji Anoroga., Perkembangan Kejahatan dan Masalahnya, Pradnya Paramita, Jakarta, 1992.

Nurmawalawati., Kriminologi, FH. Universitas Diponegoro, Semarang, 2000

R. Soesilo., Kitab Undang-Undang Hukum Pidana, Politea, Bogor, 1990.

Soedjono Dirdjosisworo., Ruang Lingkup Kriminologi, Remadja Karya, Bandung, 1996

Soerjono Soekanto, Faktor-faktor Yang 
Media Komunikasi dan Informasi Hukum dan Masyarakat

Mempengaruhi Penegakan Hukum,

Raja Grafindo Persada, Jakarta, 2002.

Sudarsono., Kenakalan Remaja, Rineka Cipta, Jakarta, 1990

WA.Bonger., Pengantar Tentang Kriminologi, PT. Pembangunan Ghalia Indonesia, 1977

Kitab Undang-Undang Hukum Pidana.

Undang-Undang Nomor 23 Tahun 2002 tentang Perlindungan Anak

Undang-Undang Nomor 3 Tahun 1997 tentang Peradilan Anak 